\title{
Kecemasan anak usia dini dan intervensinya (Studi kasus di TK Majaksingi)
}

\author{
Lilis Madyawati ${ }^{1 凶}$, Nurjannah ${ }^{2}$ \\ Pendidikan Guru Pendidikan Anak Usia Dini, Universitas Muhammadiyah Magelang, Indonesia \\ Pendidikan Anak Usia Dini, Universitas Islam Negeri Sunan Kalijaga, Yogyakarta, Indonesia \\ DOI: 10.31004/aulad.v4i1.84
}

Corresponding author:[lilis_madya@yahoo.co.id]

\section{Article Info}

Kata kunci:

kecemasan anak sekolah; bantuan mengatasi; emosi

\section{Abstrak}

Pendidikan anak usia dini harus terencana, distimulan dan holistik. Kecemasan yang terjadi pada anak tak dapat diabaikan. Penelitian ini mengidentifikasi kecemasan yang dialami seorang anak perempuan berusia 5 tahun 6 bulan yang bersekolah di kelompok B TK Majaksingi kecamatan Borobudur. Terdapat upaya yang dilakukan guru, dan pengelola, penyebab siswa senang/ tidak senang, kerja sama sekolah dengan orang tua, serta hasil intervensinya. Pendekatan penelitian menggunakan qualitative research dengan case study. Peneliti melakukan survey pendahuluan, field study, penelusuran literatur, dan beberapa informan. Pengumpulan data melalui indept interview, metode observasi, dan teknik dokumentasi. Analisis data secara deskripsi terinci tentang kasus, pengumpulan kategori, interpretasi langsung,membentuk pola, serta kesepadanan kata. Kecemasan dipacu kesulitan akademik, tuntutan orang tua, riwayat kesehatan buruk. Pihak sekolah memberi intervensi berupa: mengkomunikasikan kepada orang tua, pendampingan, pengulangan, dan pembiasaan, namun belum menunjukkan hasil maksimal.

\section{Abstract}

Early childhood education must be well planned, stimulated, and holistic.

Keywords:

children's anxiety;

problem solving help; emotions.
Anxiety in the children could not be ignored. This research identifies anxiety faced by a 5.6 year-old-girl in group B of Majaksingi Kindergarten Borobudur. Some efforts were provided by the teachers and school management such as investigating reasons for happiness and unhappiness of the girl, cooperating with parents, and examining the result of interventions. It is qualitative research with a case study. Researchers conducted a preliminary survey, field study, literature review, and interview. The data was collected through in-depth interviews, observation, and documentation. The data analysis of the case follows steps of category collection, direct interpretation, pattern creating, and word matching. Anxiety was triggered by academic difficulty, parents' demands, and poor health history. The school provides interventions in form of: communicating with parents, assistance, repetition, and habituation. However, the result is still less optimal. 


\section{PENDAHULUAN}

Lembaga pendidikan anak usia dini merupakan lembaga pendidikan yang diharapkan oleh para orang tua dapat membentuk anak menjadi insan berkarakter serta berilmu (Ansari, A; Pianta, R.C, 2019). Pendidikan anak usia dini merupakan suatu tahapan penting dalam tumbuh kembang anak, utamanya dalam hal pendidikan hingga masa mendatang (Amaludin, 2018). Terdapat 3 argumen pentingnya lembaga pendidikan anak usia dini: 1) PAUD merupakan landasan awal belajar untuk anak secara formal; 2) Sarana menyiapkan anak ke tingkat pendidikan berikutnya yaitu sekolah dasar; 3) Landasan penting bagi fungsi ekskutik otak anak.

Perubahan memang lebih sering membawa ketidaknyamanan. Ada rasa yang tidak bisa ditutupi begitu akan melangkah. Kondisi seperti ini tidak hanya dikeluhkan oleh orang dewasa, anakpun dapat merasakan hal yang sama. Seorang anak yang sudah sampai pada usia sekolah, sebagian waktu pada kehidupan rumah yang anak jalani serta merta digantikan dengan kehidupan di sekolah. Sangat dimungkinkan anak akan menghadapi masa- masa sulit dalam beradaptasi dengan orang- orang baru di sekolah, suasana baru, dan lingkungan baru (Amaludin, 2018). Belum lagi anak akan mempelajari banyak hal yang barangkali tidak dia dapatkan di rumah. Kondisi seperti ini dapat berlangsung sementara, dapat pula berlarut, sangat tergantung dari kondisi mental anak.

Kecemasan yang terjadi pada anak menarik untuk dikaji. Masalah kecemasan di sekolah yang terjadi pada anak tidak dapat diabaikan. Usia anak dini (hingga 6 atau 8 tahun) belum mampu mengekspresikan dirinya dengan baik (Amaludin, 2018). Anak yang mengalami kecemasan mungkin memiliki tingkat kelekatan tinggi dengan orang tua, mudah kaget, menangis atau mengamuk, kurang tidur, sakit kepala atau sakit perut. Kecemasan pada anak di sekolah dapat terjadi kapan saja. Kembali ke sekolah setelah jeda atau waktu liburan yang panjang, pindah sekolah yang baru, kehilangan orang terdekat, pulih dari sakit yang cukup lama dapat mengakibatkan anak menjadi cemas di sekolah.

Menurut Shanchez, et.al (2018) pada anak dengan usia 4- 6 tahun yang pernah mengalami kecemasan umumnya memiliki kecerdasan rata- rata atau di atas rata- rata. Namun, sangat dimungkinkan anak- anak ini mengalami masalah pendidikan atau juga masalah sosial yang lebih serius bila ketakutan dan kecemasan ini tidak teratasi dan terus menghambatnya untuk berteman dan bersekolah.

Seperti yang pernah dituturkan guru $\mathrm{H}$ seorang pendidik di TK Majaksingi kepada peneliti (Pebruari, 2020). Kecemasan yang dialami seorang anak di sekolah dapat muncul sebagai rasa takut atau khawatir, tetapi juga bisa membuat anak mudah tersinggung dan marah. Ibu Y wali murid TK Majaksingi menyampaikan kepada peneliti, bahwa putrinya (D), sering menangis ketika berada di sekolah, padahal teman- temannya bersahabat. Ternyata hal ini disebabkan hadirnya guru baru di PAUD Y tempat $D$ bermain sambil belajar.

Terdapat anak yang menyimpan kecemasan disebabkan kekhawatirannya dipendam sendiri. Hal ini tampak pada gejala fisiknya, seperti mudah marah dan tersinggung. Hal- hal yang terjadi dalam kehidupan seorang anak dapat menjadi stres dan sulit untuk diatasi. Umumnya yang terjadi dan dialami anak karena faktor kehilangan. Kehilangan atau kecenderungan berpisah dengan orang tua, kehilangan rasa aman dan nyaman, kehilangan kegembiraan dapat memicu munculnya kecemasan pada anak (Cowden, P. 2019).

Penyebab dari kecemasan pada anak ini dipengaruhi oleh beberapa faktor, misalnya menghadapi lingkungan baru serta dukungan orang tua/ keluarga terhadap pendidikan. Lingkungan dan orang-orang asing yang ditemui anak, perlakuan di sekolah, disiplin dan tata tertib yang harus diikuti anak merupakan sumber utama stres, kecewa, dan cemas (Saddik, et.al, 2020). Ketika anak menghadapi tugas- tugas atau instruksi yang diberikan guru juga dapat memicu terjadinya kecemasan. Bila anak mendapat tekanantekanan berupa tugas- tugas yang harus diselesaikan di sekolah dan anak belum dapat melakukannya dengan baik. Tugas- tugas sekolah dapat memunculkan berbagai reaksi afektif negative yang mempengaruhi keadaan anak.

Anak sekolah yang menunjukkan reaksi afeksi negatif akan mengalami kecemasan, kebosanan dan stres sehingga dapat menjauhi tugas- tugas akademik, malas ke sekolah, bahkan dapat pula blocking (berhenti sekolah). Target kurikulum yang terlalu tinggi, iklim pembelajaran di sekolah yang kurang kondusif, tugas- tugas yang padat, disiplin sekolah yang ketat, iklim sekolah yang kurang nyaman, sarana prasarana sekolah yang kurang memadai juga merupakan faktor penyebab terbentuknya kecemasan pada anak (Mano, 2017).

Terdapat beberapa upaya yang dapat dilakukan oleh orang tua, guru maupun anak dalam menghadapi kecemasan. Seperti diungkapkan oleh Capurso, et.al. (2020), orang tua dan guru di sekolah 
dapat mengajak anak untuk berbicara, melakukan obrolan ringan sambal mencari tahu kondisi yang sedang dialami oleh anak. Orang tua maupun guru berusaha mengerti apa yang dirasakan oleh anak. Orang tua maupun guru berusaha mengerti apa yang dirasakan oleh anak. Orang tua juga dapat memahamkan kepada anak bahwa kecemasan yang sedang dialaminya dapat memberikan dampak pada kesehatan fisik dan mental.

Cara lain yang dapat dilakukan guna mengatasi kecemasan pada anak di sekolah yaitu dengan cara memberikan pemahaman kepada anak, mendampingi dan sesekali menemani anak sewaktu berkegiatan, atau memberikan reward. Dapat pula dilakukan melalui intervensi psikologis maupun peningkatan pengetahuan guru dalam hal mengatasi anak yang mengalami kecemasan di sekolah dengan pendekatan psikodinamika, pendekatan humanistik, pendekatan biologis, hingga pendekatan belajar (Eisen, A; Engler, L, 2006).

Penelitian ini akan mengidentifikasi dinamika kecemasan yang dialami anak di sekolah, upaya apa saja yang telah dilakukan guru dan pengelola dalam hal kaitannya dengan teori perkembangan. Dalam penelitian ini juga akan diungkap hal- hal yang menyebabkan siswa senang dan tidak senang/ tidak nyaman di sekolah. Hal- hal yang terkait dengan kerja sama sekolah dengan orang tua dalam hal menangani dan mengatasi kecemasan yang terjadi pada anak di sekolah serta bagaimana hasilnya juga digali, diinterpretasi, serta dikaji oleh peneliti.

Penelitian ini akan memberikan manfaat bagi pengembangan ilmu pengetahuan, menambah pengetahuan dan wawasan bagi guru, pengelola, dan orang tua dalam memberikan intervensi pada anak yang mengalami kecemasan di sekolah. Manfaat lain dari penelitian ini sebagai wacana bagi semua pihak serta berkontribusi pada ilmu pengetahuan psikologi perkembangan anak.

\section{METODOLOGI}

Pendekatan penelitian yang digunakan yaitu qualitative research (Taylor, S.J \& Bogdan, R. 2015 dengan prosedur penelitian menghasilkan data deskriptif berupa kata- kata tertulis atau lisan dari orangorang dan perilaku yang dapat diamati. Penelitian kualitatif ini akan lebih diarahkan pada penggunaan case study. Pendapat Lincoln dan Guba (1981) menyebutkan sebagai penelitian mendalam dan mendetail tentang segala sesuatu yang berhubungan dengan subyek penelitian. Peneliti akan menggunakan case study untuk mengungkapkan tentang kecemasan yang dialami anak di sekolah, intervensi apa yang diberikan guru dan pengelola, hal yang dapat menyebabkan siswa senang dan tidak senang/ tidak nyaman, kerja sama sekolah dengan orang tua serta hasilnya.

Peneliti akan berusaha memahami dan memaknai pandangan serta kejadian pada subyek penelitian dalam rangka menggali tentang dinamika kecemasan yang terjadi pada anak di sekolah. Pemilihan rancangan dan metode ini didasari pada fakta bahwa tema yang dikaji termasuk unik dan merupakan perilaku menyimpang.

Subyek penelitian ini yaitu seorang anak yang mengalami kecemasan di sekolah bernama ADN berjenis kelamin perempuan. Pada saat penelitian subyek berusia 5 tahun 6 bulan. ADN berada di TK kelompok B di TK Majaksingi kecamatan Borobudur kabupaten Magelang.

Agar pelaksanaan penelitian lebih terarah dan sistematis, maka peneliti menyusun tahapan penelitian meliputi empat tahapan, yaitu tahap pra-lapangan, penelusuran literatur, tahap pekerjaan lapangan, dan tahap pelaporan. 1) Tahap pra-lapangan. Peneliti mengadakan survey pendahuluan dengan cara mencari calon subyek penelitian. Dalam hal ini peneliti melakukan field study terhadap latar penelitian, mencari data dan informasi tentang anak yang mengalami kecemasan. Peneliti juga melakukan penelusuran literatur, menyusun rancangan penelitian (Noor, 2008). Tahap pekerjaan lapangan, dalam tahap ini peneliti memasuki dan memahami latar penelitian dalam rangka pengumpulan data.

Peneliti juga menggunakan beberapa informan, yaitu guru, kepala sekolah, dan orang tua. Digunakannya informan tersebut dengan argumen bahwa mereka mengetahui dengan pasti gejala-gejala kecemasan yang terjadi pada anak di sekolah.

Teknik pengumpulan data dalam penelitian ini menggunakan: 1) wawancara mendalam (indept interview), 2) Observasi, observasi yang dilakukan menggunakan observasi berstruktur yaitu dengan melakukan pengamatan menggunakan pedoman observasi terkait indikator- indikator kecemasan; 3) Teknik dokumentasi, dokumentasi dalam penelitian ini berupa dokumen- dokumen atau catatan- catatan tumbuh kembang maupun dokumen- dokumen penilaian yang dimiliki guru terkait subyek penelitian (anak ADN yang mengalami kecemasan). Dapat berupa anecdotal record yang dibuat guru sesuai indikator kecemasan. Wawancara dilakukan kepada guru, kepala sekolah/ pengelola, dan orang tua siswa. 
Observasi dilakukan terhadap anak yang cemas, guru, kepala sekolah, dan orang tua. Dokumentasi dilakukan penelusuran terhadap dokumen- dokumen yang dimiliki sekolah terkait dengan anak yang mengalami gangguan kecemasan di sekolah (ADN). Observasi pada anak yang mengalami kecemasan meliputi gejala/ kondisi fisiologis dan kondisi psikologis (Kaplan; Sadock; Grebb, 2010).

Instrumen penelitian yang dipakai guna mengumpulkan data berupa pedoman wawancara dan pedoman observasi. Pada tabel 1 adalah kKisi-kisi Pedoman wawancara dan Pedoman Observasi yang digunakan. Melakukan analisis data pada studi kasus merupakan suatu hal yang agak sulit karena teknik dan strateginya belumlah teridentifikasikan secara baik. Padahal setiap penelitian hendaknya diawali dengan strategi analisis yang umum yang memiliki prioritas tentang apa yang akan dianalisis dan mengapa. Menurut Creswell (2016) pada studi kasus analisis datanya dilakukan secara deskripsi terinci tentang kasus beserta setingnya. Apabila suatu kasus menampilkan kronologis suatu peristiwa maka dalam menganalisisnya memerlukan banyak sumber data untuk menentukan bukti pada setiap fase dalam evolusi kasusnya. Apalagi untuk seting kasus yang únik', peneliti menganalisis informasi untuk menentukan bahwa peristiwa itu terjadi sesuai setingnya. Mengacu pendapat Stake (2005), maka analisis data dan interpretasi data dalam penelitian ini meliputi: 1) pengumpulan kategori, 2) melakukan interpretasi secara langsung; 3) peneliti membentuk pola dan mencari kesepadanan antara dua atau lebih kategori; 4) mengembangkan generalisasi naturalistik melalui analisis data. Generalisasi ini diambil melalui orang- orang yang dapat belajar dari suatu kasus, dapat berupa kasus mereka sendiri maupun menerapkannya pada sebuah populasi kasus. Selanjutnya analisis data dilakukan melalui teknik triangulasi.

\section{Tabel 1. Pedoman Wawancara}

\begin{tabular}{cl}
\hline No & \multicolumn{1}{c}{ Hal yang ditanyakan } \\
\hline 1 & Kapan anak mengalami kecemasan? \\
2 & Apa yang membuat anak mengalami kecemasan? \\
3. & Kapan ciri- ciri kecemasan akan muncul? \\
4 & Bagaimana prilaku anak ketika menghadapi sekolah? \\
5 & Bagaimana aktivitas anak ketika berada di sekolah? \\
6 & Bagaimana aktivitas anak ketika berada di rumah? \\
7 & Bagaimana ciri- ciri ketika anak mulai mengalami kecemasan? \\
8 & Apa yang orang tua ketahui tentang prilaku anak? \\
9 & Bagaimana tindakan orang tua dalam menangani prilaku kecemasan pada anak? \\
10 & Bagaimana tindakan guru dalam menangani prilaku kecemasan anak? \\
11 & Bagaimana play therapy dipergunakan guru untuk mengurangi anxiety pada anak? \\
12 & Bagaimana dampak/ kondisi anak sebelum/ setelah diberikan play therapy? \\
\hline
\end{tabular}

Tabel 2. Kisi- kisi Observasi

\begin{tabular}{lll}
\hline $1 \quad$ Kondisi Fisiologis & Perubahan raut wajah \\
& Menangis \\
& Pusing ketika berangkat ke sekolah \\
& Kaki dan tangan dingin \\
& Menggigit jari \\
& & Konsentrasi \\
& Kondisi Psikologis $\quad$ Respon terhadap kegiatan \\
& Interaksi dengan teman- teman dan guru \\
& Kepercayaan diri di sekolah \\
\hline
\end{tabular}

\section{HASIL DAN PEMBAHASAN}

Hasil penelitian dilakukan berdasarkan hasil wawancara, observasi dan teknik penelusuran dokumen terkait dengan kecemasan anak ADN yang dialami di sekolah. ADN mengalami kecemasan yang merupakan hasil perpaduan dan internalisasi antara kerentanan kognitif dan kepribadian.

Subyek ADN anak pertama dari dua bersaudara. ADN tinggal bersama kedua orang tuanya dan seorang adiknya yang masih bayi. Saat ini subyek di kelompok B taman kanak-kanak di Majaksingi. ADN belajar di taman kanak- kanak semenjak usianya 4 tahun 5 bulan, waktu itu ia di kelompok A (layanan usia 4- 5 tahun). Selama di kelompok A, subyek cenderung tidak bermasalah.Riwayat kasus ADN dimulai 
ketika dia duduk di taman kanak- kanak kelompok B (layanan usia 5- 6 tahun). Hal ini dikarenakan di kelompok B, subyek sudah mulai sering dinilai secara akademik. Kondisi ini diperparah ketika orang tua sering berpesan bahwa ADN harus pandai karena tidak lama lagi akan masuk jenjang pendidikan sekolah dasar.

'Tidak lupa...Ayo yang rajin dan pandai ya kamu..harus bisa..mau sekolah ke SD kan?...'

Harapan orang tua ini bagi ADN merupakan sebuah beban. Padahal di sisi lain harapan orang tua tidak akan bisa dipenuhi oleh ADN. Hari demi hari ketika ADN mengambil tugas-tugas ke sekolah ditemani ibunya saat pandemi dan mencoba mengerjakan tugas- tugas sekolahnya, subyek selalu merasa sulit.

Keadaan ADN dalam hal tugas- tugas akademik yang ditunjukkan dengan nilai/ capaian perkembangan pada dokumen yang ada pada guru tak pernah menunjukkan capaian yang memuaskan. Berdasarkan hal ini orang tua ADN meminta para guru (dengan agak memaksa) untuk dapat turut menekan ADN terkait dengan pengerjaan tugas- tugas.

'Bu guru coba dech anak saya.hari ini ada tugas apa? Suruh kerjain dengan baik dia ya'...tolong ya bu guru..betul ya..dia harus bisa...'

Belum lagi hal ini membuat orang tua subyek bersikap keras. Subyek dengan riwayat kesehatan sejak kecil dengan kondisi kesehatan yang tidak menguntungkan ini sering mengeluh merasa sulit dan tidak pernah bisa mengerjakan tugas- tugas sekolah, sementara keseharian ibunya disibukkan dengan mengurus adiknya yang masih bayi, ayahnya pekerja buruh yang selalu pulang sore hari.

Tidak jarang ibunya mengata- ngatai ADN sebagai anak yang bodoh dan tak bisa berpikir. Tak jarang ADN sering lupa, sulit dalam mempersepsi sesuatu, dan sukar dalam mengembangkan ide. Hal ini tampak ketika guru meminta ADN untuk menyebut deretan bilangan dan gambar pada secarik kertas, padahal baru saja guru mengajarinya. Begitu pula ketika ibunya menanyakan bentuk- bentuk pola geometri di halaman sekolah di suatu pagi, ADN dengan susah payah berusaha mempersepsi bentukbentuk itu, namun tak pernah berhasil. Pada saat ADN bersama ibunya ke sekolah di hari lain untuk menyerahkan dan mengambil tugas- tugas dari sekolah, tampak ADN bermuka muram dan murung saat terlihat ibu guru F menyambutnya. Tak lama kemudian dia menangis. Ibu F berusaha menenangkan. Untuk kesekian kalinya ibu ADN membantu mengerjakan menghubungkan gambar dan bilangan, ibu guru $F$ membimbingnya, ADN terlihat tidak dapat berkonsentrasi dengan baik.

Terbatasnya dalam hal berkonsentrasi menyebabkan ADN rentan stres jika harus menghadapi tugas dengan aktivitas mental yang lama. Terhambatnya intelektual ADN untuk memenuhi harapan orang tua, memunculkan perasaan inferior yang pada akhirnya dapat memicu terjadinya kecemasan. Pemicu kecemasan yang dialami ADN tidak hanya tuntutan dari orang tua, melainkan juga adanya tuntutan pencapaian akademik di sekolah. Apalagi memang karakteristik subyek yang mudah rentan terhadap stres dan frustasi.

Kapasitas intelektual yang terbatas menyebabkan subyek tidak memiliki pilihan problem solving untuk mengatasi masalah dan kecemasan yang dihadapinya, sehingga yang terjadi berupa reaksi kecemasan. Pada awal riwayatnya di kelompok TK B, ADN pernah mencoba mereduksi kecemasannya dengan menarik diri dari lingkungannya. ADN cenderung lebih menghindari subyek/ hal- hal yang dapat mengakibatkan dirinya cemas, misalnya teman- temannya dan gurunya. ADN merasa semua temannya pintar, dan dia tidak mampu, tidak bisa menyamai teman- temannya. ADN sangat takut dengan guru yang bersuara keras, dia berpikir bahwa ia sedang dimarahi guru dan segala yang dia lakukan dan kerjakan merupakan sebuah kesalahan. Oleh karena itu, ADN lebih memilih tidak pernah menjawab pertanyaan guru maupun bertanya kepada guru.

Mekanisme pertahanan diri (defense mechanism) konvensional ini tidak efektif mengatasi kecemasan. Hal inilah yang mengakibatkan ketegangan dan kecemasan subyek tidak berkurang. Perilaku ini kemudian berkembang menjadi teriakan yang sering tidak dapat dikembalikan saat ADN mengalami kecemasan yang hebat. Pola perilaku ini lalu diperkuat oleh tanggapan lingkungan yang diberikan guru dengan sangat terfokus pada subyek. Subyek kemudian mendapatkan dispensasi saat subyek menunjukkan perilaku berteriak atau memukul pintu maupun meja. Ketika itu subyek merasa dapat terlepas dari kecemasannya karena subyek dengan cara demikian dapat terbebas dari tugas- tugas yang membuatnya tertekan, apalagi pada tugas menulis bentuk huruf. Pada saat itu subyek juga secara tidak 
langsung mendapatkan perhatian dari orang- orang yang berada di sekitarnya. Tidak jarang subyek akhirnya didampingi dan banyak dibantu saat mengerjakan tugas- tugas sekolah.

Guru sudah pernah mencoba berkali- kali menyampaikan hal ini kepada orang tua. Tanggapan/ respon yang diberikan orang tua yaitu orang tua ADN membawa ADN ke orang pintar'. Órang pintar'menganggap bahwa ADN dirasuki kekuatan gaib. Karena karakteristik kognitif subyek yang terbatas dan ego yang melemah, ADN sulit memahami realitas. Informasi yang diterima oleh ADN dan ibunya diterima dengan secara mentah begitu saja. ADN dan ibunya meyakini bahwa dirinya benar kerasukan setan. Selain itu, pernah pula perilaku ADN semakin naik frekuensi dan intensitasnya. Saat ADN benar- benar cemas dan tegang, ADN pernah kehilangan kesadarannya dan tidak mengenali orangorang yang ada di sekitarnya.

Peran guru dalam menghadapi permasalahan sosial emosional pada anak usia dini di TK Majaksingi dengan melakukan penegasan, pengulangan, mengingatkan dan pembiasaan. Cara- cara ini memudahkan guru untuk melatih anak meningkatkan perkembangan sosial emosionalnya. Solusi yang dilakukan guru dalam mengatasi permasalahan sosial emosional anak usia dini termasuk kecemasan yaitu bekerja sama antara guru dan guru, guru dengan ketua yayasan/ pengelola, serta guru dengan orang tua, yaitu: 1) menggunakan aturan yang sama antara aturan di rumah dengan aturan di sekolah; 2) memberikan penegasan; 3) dengan pengulangan yang sama di rumah dan di sekolah; 4) mengarahkan anak guna melakukan pembiasaan yang sama; 5) mengingatkan apa yang harus dilakukan dan tidak dilakukan anak guna mengatasi permasalahan tersebut.

Kerja sama ini dilakukan guru atau kepala sekolah saat orang tua mengambil tugas dan menyerahkan tugas (pada kondisi pandemi) untuk memberikan apa yang terjadi pada ADN. Selain itu pihak sekolah juga mengarahkan orang tua agar dapat menyesuaikan dengan aturan sekolah yang telah dibuat oleh guru.

Adapun hal- hal yang membuat ADN suka dan nyaman di sekolah, hal ini terjadi saat ADN masih berada di TK kelompok A (layanan usia 4- 5 tahun). ADN menyukai figur guru A yang sering mengajaknya bercerita hampir di setiap kesempatan. Guru A sangat lembut bertutur kata dan baik hatinya. Guru yang seorang ASN (Aparatur Sipil Negara), berusia 45 tahun dan telah 10 tahun mengabdi di TK Majaksingi. ADN suka pada guru A karena banyak menyisihkan waktu untuk mengajaknya berbicara dengan santainya, seperti layaknya seorang teman. Tidak jarang guru A ini banyak memberikan kesempatan pada ADN melakukan apa saja di sekolah, asal itu tidak berbahaya. Pernah ADN mencoba berusaha menaiki pohon jambu yang ada di halaman sekolah, mengais- ais tanah dengan jari- jarinya, guru A bahkan menemani sambil mengawasi. Sesekali guru A juga bercerita tentang orang tuanya serta meminta ADN juga melakukan hal yang serupa.

Hasil analisis terkait hal-hal yang dapat membuat ADN tidak suka, di antaranya adanya guru yang terlalu mendikte, mengatur berlebih terhadap hal yang disuka dan dilakukan anak, tanpa memberikan kesempatan ADN untuk dapat mandiri dengan baik. Terdapat pula guru yang sering menjanjikan sesuatu, memberi atau memperlihatkan sesuatu, namun tidak dipenuhi oleh guru tersebut dan akhirnya ADN kecewa.

Telah banyak upaya yang dilakukan guru, kepala sekolah, dan pengelola terkait anak yang mengalami kecemasan di sekolah. Guru dan tenaga kependidikan lainnya menyarankan kepada orang tua untuk sering mengajak berbicara tentang hari- harinya di sekolah, tentang siapa teman duduknya atau tentang hal- hal yang didapatkan dari sekolah di hari- harinya (Olore, 2017). Di masa anak sekolah, sangat penting bagi orang tua dapat bekerja sama dengan guru agar anak tidak dirundung kecemasan. Disarankan orang tua juga hendaknya memberikan kepercayaan yang penuh kepada sekolah dan guru. Dengan ini orang tua akan dapat lebih mudah melepas anak- anaknya. Begitu pula halnya dengan pentingnya orang tua satu dengan lainnya juga saling menjalin komunikasi dengan baik dan sehat. Jalinan komunikasi di era modern ini dapat dibangun melalui berbagai media sosial, seperti: whatshapp group, facebook, telegram, dll.

Kuusimaki, Malmivaara; dan Tirki, K (2019) menyatakan bahwa komunikasi dengan orang tua murid lain juga dapat membantu mengurangi kekhawatiran orang tua. Jalinan komunikasi yang baik dengan sesama orang tua dan guru akan berakibat pada orang tua yang juga merasa dekat dengan lingkungan sekolah anak.

Dari berbagai upaya yang telah dilakukan banyak pihak menunjukkan bahwa penanganan atau upaya mengatasi kecemasan pada ADN belum menunjukkan hasil yang maksimal. Kecemasan yang dialami ADN saat berada di sekolah atau mengerjakan tugas- tugas belum dapat diminimalkan. 
Kecemasan merupakan hal yang biasa dialami baik oleh para orang dewasa maupun anak- anak. Gangguan kecemasan yang terjadi pada anak di sekolah merupakan hasil dinamika dari kerentanan kognitif dan kepribadian. Subyek penelitian menunjukkan mengalami cognitive deficite yang tercermin dalam proses kognitif, seperti: persepsi, daya ingat, mengembangkan ide, evaluasi, dan penalaran. Hal ini juga dapat dilihat dari gambaran aspek intelektual subyek (Waldfogel, J., \& Washbrook, E.V, 2010). Subyek memiliki kesulitan berpikir secara logis serta sering mengalami kesulitan dalam berkonsentrasi.

Terbatasnya seorang anak dalam hal berkonsentrasi dapat menyebabkan seseorang semakin rentan stres jika harus menghadapi tugas yang menggunakan aktivitas mental yang cukup lama. Terkendalanya beberapa aspek kognitif tadi menyebabkan subyek merasa sulit untuk mengikuti berbagai kegiatan di sekolah. Subyek kesulitan untuk dapat berprestasi seperti anak normal lainnya.

Kepemilikan perasaan inferior juga pada akhirnya dapat memicu perasaan cemas. Pemicu kecemasan yang dialami subyek tidak hanya tuntutan dari orang tua, melainkan juga pada tuntutan pencapaian akademik di sekolah. Burgess, S. et al (2014) melalui penelitiannya mengungkapkan bahwa sebagian besar keluarga menuntut kuat kepada anak untuk berprestasi akademis di sekolah. Sekalipun penelitian ini juga mempertimbangkan jarak antara rumah dan sekolah. Lebih lanjut disampaikan faktor lain yang mempengaruhi prestasi sekolah anak yaitu kondisi sosio ekonomi lembaga pendidikan yang dimaksud. Hal ini berkaitan dengan kesediaan sarana prasarana yang dimiliki Lembaga PAUD.

Karakteristik kepribadian subyek juga rentan terhadap stres dan frustasi. Hal ini didukung dengan pendapat Peters, W.J. (2015) yang menyatakan bahwa terbatasnya kapasitas intelektual berpengaruh pada ketahanan emosi, sehingga menjadi lebih mudah emosi. Sekalipun proses kognitif dan proses kepribadian merupakan dua hal yang berdiri sendiri, namun keduanya saling mempengaruhi. Hal ini dapat dijelaskan bahwa seorang anak yang memiliki kapasitas intelektual terbatas maka kepribadiannyapun menjadi tidak matang dan kurang rasional.

Freud (dalam Feist, J. 2017) berpendapat bahwa anak dengan kapasitas kognitif yang terbatas mengalami kelemahan dalam fungsi ego. Ego yang normal akan berguna untuk menggali dan mempelajari realitas, memahami akibat dari sebuah tindakan, serta belajar untuk menahan keinginan yang secara sosial dapat diterima.

Guru memegang peran yang penting dalam rangka mengurangi kecemasan yang terjadi pada anak di sekolah. Elliott, J.G., \& Place, M. (2017) melakukan kajian terhadap kecemasan yang terjadi pada anak di sekolah. Kecemasan sekolah juga dapat diindikasikan atau diukur dari seringnya anak membolos atau intensitas ketidakhadirannya yang tinggi. Kedua hal ini dapat menggambarkan seorang anak yang mengalami kecemasan di sekolah.

Berbagai cara telah dilakukan oleh guru- guru pihak TK Majaksingi. Guru telah banyak memberi pengertian, mendampingi anak saat mengerjakan tugas, meminta anak ke sekolah lebih awal, bahkan memberikan reward. Upaya ini sudah dilakukan, namun anak masih juga tampak cemas. Prilaku yang ditunjukkan bisa menangis hingga berteriak- teriak. Keterampilan dan pengetahuan guru dalam mengatasi kecemasan pada anak memang kurang. Guru menjadi mudah panik ketika menghadapi anak cemas. Biasanya, karena merasa sulit, tidak jarang anak ini dibiarkan oleh guru. Hal ini berakibat pada guru yang menjadi kurang perhatian serta kurang melibatkan anak dalam berbagai kegiatan.

Killu, dkk. (2016) berpendapat bahwa kecemasan turut dipengaruhi oleh faktor kepribadian. Seseorang yang mengalami gangguan kepribadian memiliki rasa cemas yang berlebihan. Rasa cemas akibat gangguan kepribadian ini biasanya kurang dapat mengakui perasaan negative terhadap orang lain. Gejala yang dialami dapat meliputi ketidakpedulian terhadap hubungan social dan jangkauan ekspresi emosi yang terbatas. Seidler (2020) juga mengungkapkan bahwa 1) pencegahan yang diprogramkan sekolah hanya memiliki dampak kecil terhadap depresi dan kecemasan; 2) dampak dari intervensi yang diberikan sekolah baru akan tampak dengan durasi waktu 6- 12 bulan sejak diberikannya pencegahan sebagai bentuk intervensi; 3) Jenis/ program pencegahan serta banyaknya personal sangat mempengaruhi keberhasilan intervensi; 4) untuk kasus anak yang cemas hingga depresi harus lebih diupayakan dan ditargetkan; 5) Hendaknya sekolah memiliki perencanaan yang diprogramkan secara baik agar anak- anak memiliki mental yang sehat.

Anak yang mengalami kecemasan di sekolah pastinya disebabkan oleh faktor-faktor yang memicu munculnya rasa cemas. Rasa takut, keadaan yang mengancam, disiplin sekolah yang sangat ketat, hingga tugas- tugas sekolah yang terlampau banyak dan berat dapat menjadi sumber terjadinya kecemasan pada anak. Sebaliknya, semakin menyenangkan tatanan lingkungan fisik akan memberikan dampak positif bagi proses anak berkegiatan, bermain sambil belajar. Terkait dengan hal ini, kecemasan yang dialami AND 
lebih pada adanya rasa takut serta tekanan untuk berprestasi dari orang tuanya. AND sering mengalami kondisi yang terancam akibat tuntutan dari orang tuanya.

Seperti halnya yang disampaikan oleh Panjaitan (2014) bahwa anak memiliki kegemaran dalam mewarnai, menggambar, atau melukis. Usai anak berkegiatan, guru dapat meminta anak guna becerita/ berkisah tentang karyanya kepada semua teman maupun gurunya. Memang, hasil karya anak tentu tidak sebagus hasil karya orang dewasa/ seniman profesional. Namun setidaknya akan bangga dan merasa senang bahwa karya- karyanya dihargai dan diketahui banyak orang; 5) mengajari anak untuk dapat bekerja secara berkelompok. Kegiatan ini dapat diawali dengan membentuk kelompok kecil dan meminta anak untuk dapat menyelesaikan suatu tugas kecil bersama di dalam kelompok. Melalui hal ini akan dapat mendidik anak menjadi anak yang dapat berbaur dengan teman- temannya serta dapat bekerja sama dengan baik; 6) menyampaikan pelajaran dan pesan dengan cara yang tepat. Bila guru menyampaikan pelajaran secara tepat, maka anak dapat lebih antusias setiap kali bila guru menyampaikan pelajaran.

Dalam mengurangi/ mereduksi kecemasan yang dialami anak di sekolah diperlukan juga upaya lain yaitu kerja sama sekolah dengan orang tua murid. Dalam kasus ADN, pihak sekolah pernah berupaya memberikan intervensi kepada anak melalui orang tuanya. Tidak jarang kepala sekolah mengingatkan orang tua ADN untuk tidak terlalu banyak menuntut kepada anak. Sekalipun demikian hal ini hanya bertahan beberapa waktu, setelah itu orang tua Kembali menekan ADN agar dapat berprestasi .

Berbagai survey dan kajian telah berhasil membuktikan bahwa kerja sama antara pihak sekolah dan orang tua siswa sangatlah penting guna terjaminnya keberhasilan siswa, baik aspek prestasi akademik maupun aspek karakter. Sejalan dengan yang ditulis oleh Epstein, J.L. dalam bukunya yang berjudul 'School, Family, and Community Partnerships: Your handbook for Action, beberapa keterlibatan keluarga atau masyarakat dalam upaya pendidikan di sekolah akan dapat meningkatkan iklim sekolah serta keberhasilan siswa di sekolah.

Mengurangi kecemasan sekolah yang terjadi pada anak, juga memerlukan peran guru dan orang tua. Beberapa hal yang dapat dilakukan oleh para orang tua di antaranya:1) Orang tua dapat bercerita senangnya bersekolah. Menyampaikan kepada anak bahwa di sekolah ada teman- teman baru, ruang kelas yang nayman dan indah, mendengarkan cerita dan menyanyi, dll. Anak akan bersemangat untuk bersekolah; 2) memperkenalkan situasi baru pada anak. Hal ini dapat dilakukan, misalnya mengajak anak pergi ke sekolah barunya dan banyak melihat- lihat, mengenalkan anak dengan gurunya. Ini akan membuat anak nyaman dengan situasi yang ada.

Ada beberapa hal yang diduga menjadi sebab anak usia dini nyaman dan senang berada di sekolah. Hal yang dimaksud meliputi: 1) Bila guru menyampaikan pesan- pesan dan muatan kegiatan dengan cara menyenangkan. Hal ini dapat dilakukan melalui menyanyi, mewarnai, dan banyak kegiatan lain yang menyenangkan; 2) Guru mengajari anak untuk belajar semuanya sendiri. Kurangi membantu anak dalam mengerjakan sesuatu. Orang dewasa/ guru di sekolah dapat sering membiarkan anak melakukan pengembangan kreativitas; 3) kalau guru banyak mengajak anak berdiskusi kecil- kecilan. Ini dilakukan agar anak tidak bosan dengan sering mengajak anak berinteraksi dan berkomunikasi. Sebagai contoh ketika guru mencoba bertanya mengenai pendapat dari sebuah cerita yang baru saja dibaca. Dengan ini anak akan banyak belajar menyampaikan gagasan dan pikiran mereka; 4) mengajari anak mengenalkan sesuatu yang mereka buat. Sebagai contoh, ketika anak berhasil dan sudah selesai menggambar, guru dapat meminta anak memamerkan dan menceritakan tentang karyanya tersebut.

Anak sebagaimana yang dititipkan Allah swt. kepada orang tua harus dipertanggungjawabkan dengan baik di hadapan Allah swt. Q.S. al-Tahrim 66: 6

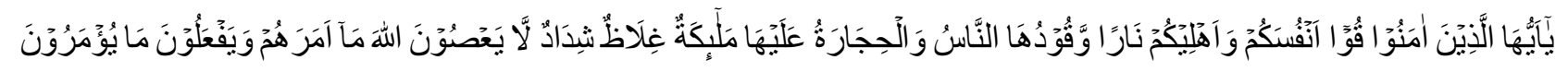

Hai orang- orang yang beriman, peliharalah dirimu dan keluargamu dari api neraka yang bahan bakarnya adalah manusia dan batu, penjaganya malaikat- malaikat yang kasar, keras, dan tidak mendurhakai Allah terhadap apa yang diperintahkan- Nya kepada mereka dan mereka selalu mengerjakan apa yang diperintahkan.

Telah banyak penelitian sejenis tentang kecemasan yang terjadi pada anak. Novelty dan kelebihan dari penelitian ini mengungkapkan dinamika kecemasan yang terjadi pada anak di sekolah dengan intervensi yang diberikan oleh Lembaga dan guru.. 


\section{KESIMPULAN}

Masalah kecemasan yang terjadi pada anak di sekolah tidak dapat diabaikan. Kecemasan yang dialami anak sangat dinamis. ADN tergolong anak dengan kondisi kognitif yang kurang menguntungkan. Kondisi ini yang turut mewarnai kepribadiannya dan berdampak pada kecemasan yang dialaminya. Upaya mengurangi kecemasan telah dilakukan guru, kepala sekolah/ pengelola, maupun orang tua. Intervensi tersebut berupa: mengkomunikasikan kepada orang tua, membantu dan mendampingi tugas- tugas sekolah, melakukan penegasan, pengulangan, mengingatkan, dan pembiasaan. Mengingat kecemasan ini sangat unik dan merupakan internalisasi dari kerentanan kognitif dan kepribadian, maka intervensi yang telah diberikan belum mampu menunjukkan hasil yang maksimal, kecemasan belum dapat diminimalkan. Diperlukan upaya lain untuk mengatasi hal ini.

\section{UCAPAN TERIMA KASIH}

Penulis mengucapkan terima kasih kepada Kementrian Riset dan Teknologi (kemenristekdikti), Universitas Muhammadiyah Magelang dan Dinas Pendidikan Kecamatan Prembun, Kecamatan Prambanan dan Pemerintah Kabupaten Wonosobo.

\section{DAFTAR PUSTAKA}

Amaludin, dkk. 2018. Character Education Early Childhood: Brain Based Teaching Approach. International journal of Pure and Applied mathematics. Vol. 119 No. 18. p. 1229-1245.

Ansari, A., Pianta, R.C. 2019. Starting Early: The Benefits of Attending Early Childhood Education Programs at Age 3. American Educational Research Journal. Vol. 56 No. 4. p. 1495- 1523.

Bogdan, Robert, C. dan Biklen, K.S. 1982. Qualitative Research for Education: An Introduction to Theory and Methods. Allyn and Bacon, Inc: Boston London.

Burgess, S.,et al. 2014. What Parents Want: School Preferences and School Choice. The Economic Journal. Vol. 125 No. 587. p. $1262-1289$.

Capurso, Michele, et.al. 2020. Empowering Children Through School Re-Entry Activities. Journal PsychoEducational.

Cowden, P. 2019. Communication and Conflict: Anxiety and Learning. Research ini Higher Education Journal. p. 1- 9.

Creswell, Jhon W. 2016. Research Design Pendekatan Kualitatif, Kuantitatif, dan Mixed. Yogyakarta: Pustaka Pelajar.

Eisen, A; Engler, L. 2006. Helping Your Child Overcome Separation Anxiety or School Refusel. New Harbinger Publications.

Elliot, J.G; \& Place, M. 2017. Practitioner Review: School Refusal: Developments in Conceptualisation and Treatment Since 2000. The Journal of Child Psychology and Psychiatry. Vol. 60 No. 1. p. 4- 15.

Epstein, Joyce L. 2010. School, Family, Community Partnership: Caring for the Children We Share. Phi Delta Kappan 76. No.9.

Feist, J; Feist, G; Roberts, T.A. 2017. Teori Kepribadian Buku 1 Edisi 8. Jakarta: Salemba Humanika.

Guba, E.G; Lincoln, Y.S. 1981. Effective Evaluation: Improving the Usefullness of Evaluation Results Through Responsive and Naturalistic Approaches. San Fransisco, CA: Jossey- Bass.

Kaplan, H.I; Sdaocj, B.J; Grebb, J.A. 2010. Sinopsis Psikiatri Ilmu Pengetahuan Perilaku Psikiatri Klinis. Tangerang (Indonesia): Binarupa Aksara.

Killu, K; Mach, R; Crundwell, A. 2016. Students with Anxiety in the Classroom: Educational Accomodations and Interventions. Sage journal. Vol. 125 No. 2. p. 30- 40.

Kuusimaki, A.M; Malmivaara, L.U; Tirri, K. 2019. Parents'and Teachers'Views on Digital Communication in Finland. Journal Education Research International. p. 1-7.

Mano, Jastrowski. 2017. School Anxietu in Children and Adolescents with Chronic Pain. Review Article. Hindawi Pain Research and Management. p. 1-9.

Noor, K.B.M. 2008. Case Stydy: A Strategic Research Methodology. American Journal of Applied Sciences. Vol 5. No.11.p. 1602-1604.

Olore. 2017. The Effectiveness of General and Special Education Collaboration in Middle Schools. Educational Studie Dissertations. Lesley University.

Panjaitan, H. 2014. Pentingnya Menghargai Orang lain. Humaniora. Vol. 5 No. 1. hal. 88- 96.

Peters, W.J. 2015. The Relationship Between Anxiety. Personality Characteristic, and Working Memory Performance. Thesis.Waston California. 
Saddik, Basema, et.al. 2020. Assesing the Influence of Parental Anxiety on Childhood Anxiety. https://doi.org/10.1101/2020.06.1120128371.

Sanchez, et al. 2018. The Effectiveness of School- Based Mental Health Services for Elementary- Aged Children: A Meta- Analysis. Journal of the American Academy of Child and Adolescent Psychiatry. Vol. 57. No. 3. p. 153- 165.

Seidler, A.W, et al. 2017. School- Based Depression and Anxiety Prevention Programs for Young People: A Systematic Review and meta-analysis. Clinical Psychology Review. Vol. 51. p. 30- 47.

Stake, Robert E. 2005. Case Study Methods in Educational Research: Seeking Sweet Water: InR. M. Jaeger (Ed.) Complementary Methods for research in education, 2nd Edition (p. 401- 414). American Educational Research Association: Washington, DC.

Taylor, Steven J \& Bogdan, R. 2015. Qualitative Research Methods. 4th Edition. Wiley.

University of California San Fransisco. 2018. Preventive Health and Savety in the Child care Setting. third Edition.

Waldfogel, J., \& Washbrook, E.V. 2010. Law income and early cognitive development in the UK: A report for the Sutton Trust. University of Bristol.

Yin, Rober, K. 2014. Studi Kasus Desain dan Metode. Jakarta: Rajawali Pers. 